\title{
Fungal biodeterioration of stained-glass windows in monuments from Belém do Pará (Brazil)
}

Corrêa Pinto, A. M. ${ }^{1,2}$ *; Palomar, T. ${ }^{2,3}$; Alves, L. C. ${ }^{4}$; da Silva, S. H. M. ${ }^{5}$; Monteiro, R.C. ${ }^{5}$; Macedo, M. F. ${ }^{1,2}$ Vilarigues, M. G. ${ }^{1,2}$

${ }^{1}$ Departamento de Conservação e Restauro, Faculdade de Ciências e Tecnologia, Universidade Nova de Lisboa, Campus Caparica, 2829-516 Caparica, Portugal

2 VICARTE, Research Unit Vidro e Cerâmica para as Artes, Faculdade de Ciências e Tecnologia, Universidade Nova de Lisboa, Campus Caparica, 2829-516 Caparica, Portugal

${ }^{3}$ Instituto de Cerámica y Vidrio, Consejo Superior de Investigaciones Científicas (ICV-CSIC), c/ Kelsen 5, Campus de Cantoblanco. 28049 Madrid, Spain

${ }^{4}$ C2TN, Instituto Superior Técnico, Universidade de Lisboa, E. N. 10, 2695-066 Bobadela LRS, Portugal

${ }^{5}$ Laboratório de Micologia, Departamento de Bacteriologia e Micologia, Instituto Evandro Chagas, Rod. BR-316 km 7, 67030-000, Ananindeua, PA, Brasil

* Corresponding author. VICARTE, Departamento de Conservação e Restauro, Faculdade de Ciências e Tecnologia, Universidade Nova de Lisboa, Monte da Caparica, 2829-516,

Caparica, Portugal

E-mail address: amc.pinto@ @ampus.fct.unl.pt (A. Corrêa Pinto).

(C) 2019. This manuscript version is made available under the CC-BY-NC-ND 4.0 license http://creativecommons.org/licenses/by-nc-nd/4.0/

Published in International Biodeterioration \& Biodegradation (2019) 138, 106-113 https://doi.org/10.1016/j.ibiod.2019.01.008 


\begin{abstract}
The most prominent historical buildings in Belém do Pará (Northern Brazil) have modernist stained-glass windows, which were commissioned from Europe since the end of the $19^{\text {th }}$ century. Some of them present biodegradation; however, there is no information about the microbial activity on them. The present work is focused on the biodeterioration by fungi on some of these Modern stained-glass windows. The fungal communities were collected, isolated and then identified by means of molecular methods. Additionally, a laboratory-based biodeterioration experiment was carried out to assess the fungal activity on replica glass samples with three different chemical compositions. The replica samples were inoculated with a four-fungal species mixture and incubated under optimal growth conditions for 5 months. Optical microscopy, $\mu$-PIXE, SEM-EDS and FTIR-ATR were performed to evaluate the biodeterioration of the soda-lime silicate glasses. This multidisciplinary approach showed that the inoculated spores (Aspergillus arenarioides, Fusarium oxysporum, Hortaea werneckii, and Trichoderma longibrachiatum) were able to form substantial mycelia in all replica glass samples. The main alterations observed were small crystals, hyphae fingerprints and a slight decrease on the glass surface smoothness. Despite the aforementioned damages, the soda-lime silicate glass compositions showed high resistance against the inoculated fungal species.
\end{abstract}

Keywords: Biodeterioration, fungal identification, stained-glass windows, tropical climate 


\section{Introduction}

The role of microorganisms in glass deterioration has been largely discussed during the last decades, mainly in European stained-glass windows (Drewello and Weissmann, 1997; Gorbushina and Palinska, 1999; Drewello et al., 2000; Rodrigues et al., 2014). The microbial colonization on glass windows is related to the climate and to a high concentration of air pollutants, among other factors. The main effects of biogenic attack on historical glass, include etching, pitting, leaching, discoloration, glass degradation, formation of gel layers, and intense soiling on the original glass surface, as reported in the literature (Drewello et al., 2000; Lombardo et al., 2005; Piñar et al., 2013; Rodrigues et al., 2014; Shirakawa et al., 2016). Most of these effects induce the loss of transparency, which directly affects not only the stained glass aesthetics, but also its iconographic function (Carmona et al., 2006).

Fungi are one of the most common organisms responsible for the glass surface changes, according to several publications (Kerner-Gang, 1968; Perez y Jorba et al., 1980; Callot et al., 1987; Krumbein et al., 1991, 1993; Kaiser et al., 1994; Piñar et al., 2013). It has been observed that fungal communities are more complex than it was previously estimated (SchabereiterGurtner et al., 2001), because they are able to acquire the elements needed for growth from the glass itself (Marvasi et al., 2009). The fungal species commonly identified belong to the genera Aspergillus, Cladosporium, Trichoderma, Penicillium, Chaetomium, Aureobasidium, Eurotium, Phoma, Scopulariopsis, and Rhizopus (Drewello and Weissmann, 1997). Moreover, it was observed that glass samples inoculated with fungi presented significant chemical and morphological changes on their surface in a short period of time (Gorbushina and Palinska, 1999; Rodrigues et al., 2014).

Studies focused on biodeterioration of stained-glass windows in a tropical climate are almost inexistent, even when they are exposed to adverse conservation conditions (A. Corrêa Pinto et al., 2018a). This is the case of the stained-glass windows in Latin America, where the majority of the published studies were focused on the history and the iconography of the panels (A. Corrêa Pinto et al., 2018a).

Fungal activity is significantly higher in tropical places because the temperature uses to be above $25{ }^{\circ} \mathrm{C}$ and the relative humidity between $80-100 \%$ (Drewello and Weissmann, 1997). These conditions create the perfect environment for microbial growth. According to the literature, even resistant glasses can lose their transparency when are exposed during a month to the rainy season in a tropical weather (Jones, 1945; Rodionova and Razumovskaya, 1972). Moreover, a study conducted on photovoltaic panels in São Paulo (Brazil) (Shirakawa et al., 
2015) evidenced the presence of fungi from the genera Aureobasidium, Cladosporium, Dothideomycetes and Pestalotiopsis as the major constituents of the sub-aerial biofilm grown on their surface.

The city of Belem do Pará ( $01^{\circ} 27^{\prime} 21^{\prime \prime} \mathrm{S}, 48^{\circ} 30^{\prime} 16^{\prime}$ W), Northern Brazil, is located next to the equatorial line, on the edge of the Guajará Bay. According to the Köppen-Geiger climatic classification (Peel et al., 2007), the city is situated in a region without air-dry seasons, with high-temperature values $\left(27-32{ }^{\circ} \mathrm{C}\right)$, a relative humidity over $80 \%$ and high rainfall (Cabral, 1995; Castro, 2009; Carvalho, 2013; De Carvalho and Szlafsztein, 2018). These environmental conditions are very dangerous for the conservation of $19^{\text {th }}$-century stained-glass windows from the most important historical buildings (e.g. churches, mausoleums, museums).

The aim of this study was to characterize the fungal community growing on modern stained-glass windows from three buildings in Belém do Pará (Museu do Estado do Pará, Britto Pontes mausoleum, and Basílica Santuário de Nazaré), Brazil, located in a tropical environment, and to assess the effects of the biodeterioration on historically accurate glass reproductions from the mentioned stained-glass windows.

\section{Materials and methods}

\subsection{Stained-glass windows and sites description}

The selection of the stained-glass windows was made accordingly to the following criteria: a) different distance of the buildings to the Guajará Bay (Suppl. Fig. S1), b) different provenance of the panels, and c) different chronology.

The characterized panels came from:

1) Museu do Estado do Pará (MEP), located in Cidade Velha neighbourhood. It has four articulated stained-glass windows in its stairwell, probably produced by Société Artistique de Peinture sur Verre (France) at the beginning of the $20^{\text {th }}$ century.

2) Britto Pontes Mausoleum (BPM), situated in Guamá neighbourhood. It has two panels produced by A Renascença studio (Portugal), possibly in the late years of the $19^{\text {th }}$ century.

3) Basílica Santuário de Nazaré (BSN), situated in Nazaré neighbourhood. It has a set of 56 panels produced by the Champigneulle studio (France) at the beginning of the $20^{\text {th }}$ century.

Buildings and panels have been deeply described in Corrêa Pinto et al. (2015). 


\subsection{Belém do Pará and its environment}

The geographical proximity of Belém do Pará to the equatorial line ensures similar temperature and relative humidity values throughout the year (Cabral, 1995; A. M. Corrêa Pinto et al., 2018b). In this area, there are only two defined seasons during the year: a) the winter, a rainy season which occurs from December to May, when humidity and cloudiness levels increase; b) the summer, a dry season from June to November, when the brightness level increase (Cabral, 1995; Bastos et al., 2002; Pantoja, 2016).

Even when two seasons were observed in this place, temperature and humidity are almost constant. The annual average temperature is around $27-32^{\circ} \mathrm{C}$; while the relative humidity ranges from 70 to $92 \%$. Furthermore, it has been shown that urbanized areas are linked to higher temperatures, which act as heat islands (Cabral, 1995; Silva and Travassos, 2008; Castro, 2009; Carvalho, 2013; De Carvalho and Szlafsztein, 2018). This is the case of Cidade Velha, Guamá and Nazaré neighborhoods, where are located the buildings selected to this work.

\subsection{Manufacture and $\mu-P I X E$ analysis of glass reproductions}

According to the chemical composition of historical samples, three different types of glasses were reproduced in the laboratory following the traditional production technique. The Composition 1 (C1) glass was similar to the sample from the Museu do Estado do Pará, the Composition 2 (C2) glass was similar to the sample from the Britto Pontes Mausoleum, and the Composition 3 (C3) glass was similar to the sample from the Basílica Santuário de Nazaré (Table 1). The replica glasses were analysed by $\mu$-PIXE using an Oxford Microbeams OM150 type scanning nuclear microprobe setup that includes a $160 \mathrm{eV}$ resolution SDD X-ray detector. The analysis was performed in a vacuum chamber and a $700 \mathrm{keV}$ proton beam to detect light elements such as the sodium. The use of a $2 \mathrm{MeV}$ proton beam and a $50 \mu \mathrm{m}$ thick Mylar foil in front of the detector allowed determining trace heavy elements composition while preventing detector irradiation damage. Quantitative analysis was performed with the GUPIX software (Campbell et al., 2010). 
Table 1: Chemical composition of replica glass samples analyzed by $\mu$-PIXE.

\begin{tabular}{lccc}
\hline \multirow{2}{*}{$\begin{array}{l}\text { Oxides components } \\
\text { (wt. \%) }\end{array}$} & \multicolumn{3}{c}{ Replica Compositions } \\
\cline { 2 - 4 } $\mathrm{Na}_{2} \mathrm{O}$ & $\mathrm{C} 1$ & $\mathrm{C} 2$ & $\mathrm{C} 3$ \\
$\mathrm{MgO}$ & 0.08 & 0.31 & 0.28 \\
$\mathrm{Al}_{2} \mathrm{O}_{3}$ & 2.13 & 6.67 & 3.91 \\
$\mathrm{SiO}_{2}$ & 69.15 & 67.05 & 65.67 \\
$\mathrm{P}_{2} \mathrm{O}_{5}$ & - & 0.23 & - \\
$\mathrm{K}_{2} \mathrm{O}$ & 0.46 & 1.00 & 0.91 \\
$\mathrm{CaO}$ & 7.03 & 7.85 & 8.95 \\
$\mathrm{TiO}_{2}$ & 0.04 & 0.13 & 0.10 \\
$\mathrm{~V}_{2} \mathrm{O}_{5}$ & 0.20 & 0.04 & 0.18 \\
$\mathrm{Cr}_{2} \mathrm{O}_{3}$ & 0.02 & 0.01 & 0.16 \\
$\mathrm{MnO}_{\mathrm{Fe}_{2} \mathrm{O}_{3}}$ & - & - & 0.03 \\
$\mathrm{CuO}$ & 0.09 & 0.35 & 0.40 \\
$\mathrm{ZnO}_{\mathrm{SnO}}$ & - & 0.01 & 0.23 \\
$\mathrm{PbO}$ & - & - & 0.04 \\
\hline
\end{tabular}

To prepare the glass reproductions, pure laboratory reagents were used as raw materials. The following oxides and carbonates were used: $\mathrm{Na}_{2} \mathrm{CO}_{3}, \mathrm{MgCO}_{3}, \mathrm{Al}_{2} \mathrm{O}_{3}, \mathrm{SiO}_{2}, \mathrm{P}_{2} \mathrm{O}_{5}, \mathrm{NaCl}$, $\mathrm{K}_{2} \mathrm{CO}_{3}, \mathrm{CaCO}_{3}, \mathrm{TiO}_{2}, \mathrm{~V}_{2} \mathrm{O}_{5}, \mathrm{Cr}_{2} \mathrm{O}_{3}, \mathrm{MnO}_{2}, \mathrm{Fe}_{2} \mathrm{O}_{3}, \mathrm{CuSO}_{4}, \mathrm{ZnCO}_{3}, \mathrm{SnO}, \mathrm{BaCO}_{3}$, and $\mathrm{Pb}_{3} \mathrm{O}_{4}$. The different compounds were mixed for $1 \mathrm{~h}$ in a shake-mixer to ensure its homogenisation. Each replica glass was melted in a ceramic crucible, in an electric furnace, at $1400{ }^{\circ} \mathrm{C}$ (Dwell: $24 \mathrm{~h}$ ). The glasses were blown in a crown (fire polished), annealed approximately at $600^{\circ} \mathrm{C}$ and slowly cooled for $6 \mathrm{~h}$. Samples $\left(\sim 2 \times 2 \times 0.2 \mathrm{~cm}^{3}\right)$ were, then, cut from the crown using a diamond point. This procedure permits to prepare replica glasses similar to historical ones, as traditional off-hand glass tools and techniques are used. In addition, the replica glass surface was fire polished, instead of mechanically polished, to mimic the surface characteristics of the original ones (Rodrigues et al., 2014). This methodology was also used in other glass deterioration studies (Rodrigues et al., 2014, 2018, Palomar et al., 2018, 2019).

\subsection{Biological sampling}

Samples of natural biofilms were collected in all the selected stained-glass windows from the three buildings. The biofilms were collected from their inner surface using a sterile swab into a sterile Eppendorf tube. Swabs were previously wetted in sterilized water in order to enable the removal of organic and inorganic matter deposited on the glass. The samples were collected for culture procedures and further molecular biology analyses. 


\subsection{Fungal isolation and identification by molecular techniques}

Fungal communities were inoculated into Petri plates containing Sabouraud Dextrose agar (SDA) and Lactritmel agar (LA) using a sterile loop and incubated at $26^{\circ} \mathrm{C}$, under 12:12 h light:dark cycles for 7 days.

After incubation, colonies were transferred to fresh Czapek Dox Agar medium for vigorous fungal growth. Pure cultures were used for molecular identification. Total DNA acquisition was accomplished following Najafzadeh et al. (2010) protocol. Approximately 1 $\mathrm{cm}^{2}$ was extracted from the colonies with more than 14 days of incubation and transferred to a $2 \mathrm{~mL}$ Eppendorf tube containing $400 \mu \mathrm{L}$ of $1 \mathrm{X}$ TE lysing buffer ( $\mathrm{pH} 9.0$ ) and glass beads. The mixture was vortexed for $1 \mathrm{~min}$. Then it was added $120 \mu \mathrm{L}$ of SDS (10\%) and $10 \mu \mathrm{L}$ of Proteinase $\mathrm{K}$ and fungal material was incubated at $55^{\circ} \mathrm{C}$ for $30 \mathrm{~min}$. After incubation, the material was vortexed again for $3 \mathrm{~min}$.

Subsequently, $120 \mu \mathrm{L}$ of $\mathrm{NaCl}(5 \mathrm{M})$ was added to the mixture and incubated for $60 \mathrm{~min}$ at $55^{\circ} \mathrm{C}$. Then the material was vortexed for $3 \mathrm{~min}$. After the addition of $700 \mu \mathrm{L}$ of Phenol:Chloroform:Isoamylalcohol $(25: 24: 1)$, the solution was mixed by hand for 5 min and then centrifuged at $4^{\circ} \mathrm{C}$, for $5 \mathrm{~min}$, at $14000 \mathrm{rpm}$. The supernatant was transferred to new Eppendorf tube containing $255 \mu \mathrm{L}$ of $5 \mathrm{M} \mathrm{NH}_{4}$-acetate, carefully mixed by inverting, incubated for $30 \mathrm{~min}$ on ice water and centrifuged again for $5 \mathrm{~min}$ at $4^{\circ} \mathrm{C}$ at $13000 \mathrm{rpm}$. Finally, after discarding the supernatant, the pellet was washed with $1 \mathrm{~mL}$ of ice cold $70 \%$ ethanol and centrifuged again in the previous conditions. After drying at room temperature, DNA was resuspended in 80-100 $\mu \mathrm{L} 1 \mathrm{X}$ TE buffer.

For fungi, the amplification of the internal transcribed spacers (ITS) 1 and 2 flanking the 5.8S ribosomal RNA gene was performed using forward primer ITS1 (5'TCCGTAGGTGAACCTGCGG-3') and reverse primer ITS4 (5'-TCCTCC GCT TATTGATATGC-3') as described by White et al., (1990). Electrophoresis of amplification products was performed on $1 \%$ (w/v) agarose gels, stained with SyBR TM Safe (Invitrogen, Carlsbad, California, USA) and visualized under UV light. The purification of amplified products was performed with Purelink PCR® Purification Kit (Invitrogen, Carlsbad, California, USA) following the manufacturer's protocol. The amplicons were sequenced using the ABI 3130/3130XL Genetic Analyzer (Applied Biosystems/Hitachi, Foster City, California, USA).

Pairwise sequence alignment was performed in the GenBank database (http://www.ncbi.nlm.nih.gov/BLAST/ ). Nucleotide sequences are also deposited at GenBank database. 


\subsection{Glass biodeterioration experiment}

\subsubsection{Inoculum preparation}

Four fungal strains collected from historical stained-glass windows and identified by DNA-based analysis were used. They were plated on Potato Dextrose Agar (PDA, Oxoid, UK) and incubated at $27^{\circ} \mathrm{C}$ for 30 days to enable their growth. For inoculum preparation, the spores were harvested by pipetting sterile $0.05 \%$ Tween 80 (Panreac) on the surface of the colonies and collecting the suspension. The concentration of spore suspension for each fungal species was determined with a haemocytometer and adjusted to $1 \times 10^{6}$ spores/ $\mathrm{mL}$. A mixed inoculum composed of all the four species was created to simulate a real case scenario. Aliquots of the inoculum from each single species, with the same concentration as previously mentioned, were added to a sterile flask followed by vortexing. The viability of the species was determined by plating each individual inoculum on PDA (Sequeira et al., 2017).

\subsubsection{Glass inoculation}

A set of nine replica samples from each glass composition ( 3 inoculated +3 for $0.05 \%$ Tween $80+3$ for control) were incubated for 5 months. The replica glass samples were positioned in glass Petri dishes with sterilized distilled water at the bottom, separated by a net, in order to avoid the direct contact between the glass and the water (Fig. 1).

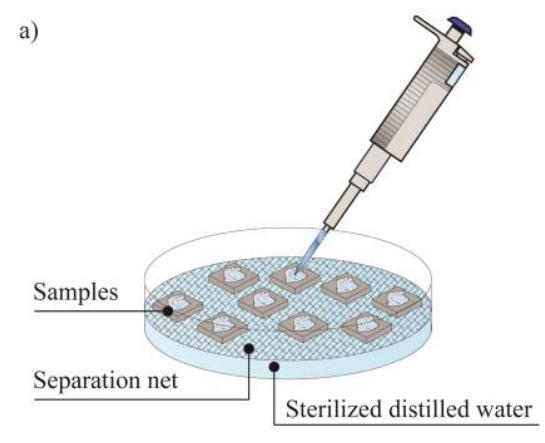

Inoculated Set
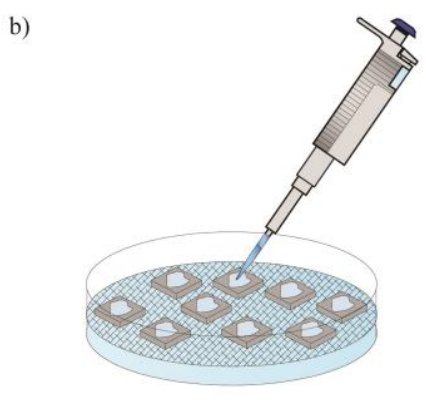

Tween Set c)

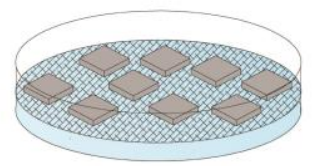

Control Set

Figure 1: Experimental design of the work: a) The Petri plate containing the inoculated samples of all compositions; b) The Tween control samples; c) The control samples.

A total of 3 Petri dishes were used to place the samples: one for inoculated samples of all compositions, one containing the samples inoculated only with $0.05 \%$ Tween 80 (Panreac), and the last one containing all the control samples. Since the spores were inoculated in the samples with $0.05 \%$ Tween 80 , a control set sample of Tween 80 was used as control, in order to identify the alterations caused by this medium in the glass surface. The Petri dishes, the net, 
and the glass samples were sterilized by dry heat at $170^{\circ} \mathrm{C}$ for $1 \mathrm{~h}$ before the inoculation. The distilled water was autoclaved at $120^{\circ} \mathrm{C}$ for $20 \mathrm{~min}$. All the samples sets were kept under the same conditions $\left(28^{\circ} \mathrm{C}, 75-95 \mathrm{RH} \%\right.$, without light). $50 \mu \mathrm{L}$ of a mixed inoculum, described in the previous section, was pipetted on the surface of the glass samples. Control samples were not inoculated. After 5 months of incubation, inoculated and control samples were analysed through several techniques.

\subsubsection{Characterization of glass samples}

Several techniques were performed to characterize the replica glass samples before and after the laboratory-based biodeterioration experiment concerning the morphological and chemical alterations on the glass surfaces. Samples were observed after incubation, before and after the soft wet cleaning procedure. It was used a cotton swab embedded in a water:ethanol (1:1) solution for this procedure.

\subsubsection{Optical microscopy}

Optical microscopy was performed using a light microscope (Axioplan 2, Zeiss) used in the reflection mode, bright field equipped with a digital camera (Nikon DMX) to observe samples surfaces before and after the cleaning procedure.

\subsubsection{Fourier Transformed Infrared Spectroscopy - Attenuated total reflectance (FTIR-} ATR)

Inoculated and control samples were analysed before $\left(\mathrm{t}_{0}\right)$ and after the incubation period $\left(\mathrm{t}_{5}\right)$ by FTIR-ATR using a portable Agilent Technologies - 4300 Handheld FTIR, with diamond cell. Spectra were acquired in attenuated total reflectance mode with $4 \mathrm{~cm}^{-1}$ resolution in the spectral range of $4000-650 \mathrm{~cm}^{-1}$. Each spectrum was the product of 32 internal scans.

\subsubsection{Scanning electron microscopy-energy dispersive X-ray spectrometry (SEM-EDS)}

Colonized glass samples were analysed by SEM to assess the microbe-surface interactions. Biodeterioration patterns were evaluated after cleaning surface procedure. Samples were mounted on sample stubs, sputter-coated with gold/palladium, and examined on a Hitachi $3700 \mathrm{~N}$ scanning electron microscope (Hitachi, Tokyo, Japan) interfaced with a Quantax EDS microanalysis system (Bruker AXS GmbH, Karlsruhe, Germany). The Quantax system was equipped with a Bruker AXS XFlash Silicon Drift Detector (129 eV spectral resolution at full width at half maximum $[\mathrm{FWHM}]-\mathrm{Mn} \mathrm{Ka}$ ). The operating conditions were: 
secondary electron mode, $10 \mathrm{kV}$ accelerating voltage, $10 \mathrm{~mm}$ working distance and $120 \mathrm{~mA}$ emission current.

\section{Results and discussion}

\subsection{Identification of fungal strains by molecular techniques}

The identified fungal strains collected from the stained-glass windows from MEP, BPM and BSN buildings are displayed in Table 2. All the five isolated fungal species belonged to the phylum Ascomycota (Hortaea werneckii, Myrothecium inundatum, Fusarium oxysporum, Aspergillus arenarioides, and Trichoderma longibrachiatum). Surprisingly, there was no fungal genus predominance between the panels.

Table 2: Phylogenetic affiliations of the ITS sequences obtained from the fungal strains isolated from the selected stained-glass windows.

\begin{tabular}{|c|c|c|c|c|c|c|}
\hline \multirow{2}{*}{ No } & \multirow{2}{*}{ Closest relative $^{a}$} & \multirow{2}{*}{$\begin{array}{l}\text { Gene bank Accession } \\
\text { number }\end{array}$} & \multirow{2}{*}{$\begin{array}{l}\text { Similarity } \\
(\%) / \\
\mathrm{QC}^{\mathrm{b}}(\%)\end{array}$} & \multicolumn{3}{|c|}{ Buildings } \\
\hline & & & & MEP & BPM & $\mathrm{BSN}$ \\
\hline 1 & Myrothecium inundatum KJ767119.1 & MK024176 & $100 / 100$ & & $*$ & \\
\hline 2 & Fusarium oxysporum MG272268.1 & MK024177 & $100 / 100$ & & $*$ & \\
\hline 3 & Aspergillus arenarioides NR_135460.1 & MK024178 & $100 / 100$ & & & * \\
\hline 4 & Trichoderma longibrachiatum MK084475.1 & MK024179 & $100 / 100$ & & & $*$ \\
\hline 5 & Hortaea werneckii MH864374.1 & MK024180 & $99 / 100$ & $*$ & & \\
\hline
\end{tabular}

Hortaea werneckii was the only species identified on MEP panel. It is a so-called blackyeast which has an extremely halotolerant character to endure in hypersaline environments, according to Gostinčar et al., (2011). This high resistance allows its growth in nearly saturated salt solution, as well as without salt (Gunde-Cimerman et al., 2000; Kogej et al., 2007), not interfering with its normal enzymatic activity. In addition, $H$. werneckii is responsible for the synthesis of some soluble solutes, such as glycerol, erythritol, mannitol (Kogej et al., 2007; Gostinčar et al., 2011). If high amounts of the aforementioned metabolites are produced, it can lead to an increase of the humidity on the glass surface.

Myrothecium inundatum and Fusarium oxysporum were identified on BPM panel. It is known that $M$. inundatum produces volatile organic compounds (VOCs), e.g. octane, acetic acid, ethanol, 1-butanol, and is also capable to decompose cellulose (Ahrazem et al., 2000; Banerjee et al., 2010). Regarding $F$. oxysporum, this species is considered a normal constituent of native soils and plants rhizosphere fungal communities (Gordon and Martyn, 1997; Fravel et al., 2003). F. oxysporum is able to secrete enzymes and metabolites during its colonization 
process (Michielse and Rep, 2009), which can enhance the development of other microorganisms increasing the glass surface decay.

Finally, in BSN panel, Aspergillus arenarioides and Trichoderma longibrachiatum were identified as colonizers of the glass surface. Aspergillus is considered by some authors as the most common genera found indoors (Amend et al., 2010; Visagie et al., 2014). Nevertheless, different strains of this genera were previously identified on historical glass as its major colonizers, e. g. A. fumigatus, A. restrictus, A. tamarii, A. penicilloides (SchabereiterGurtner et al., 2001; Carmona et al., 2006). T. longibrachiatum was previously identified on mouldy building materials from Western Europe and Scandinavia (McMullin et al., 2017), and it is known to produce acetic acid (Djian et al., 1991). This result is also in concordance with data reported by Pereira et al., (2013), concerning the dominant anemophilus fungal genera occurrence in Nazaré neighbourhood (Brazil).

It is important to highlight that Fusarium oxysporum, Myrothecium inundatum, Hortaea werneckii, Aspergillus arenarioides, and Trichoderma longibrachiatum have not been identified on stained-glass windows before. Nevertheless, studies on optical glass under tropical climate identified the presence of Aspergillus, Trichoderma, and Fusarium in its corrosion layer (Drewello and Weissmann, 1997), suggesting that these species are typical from the geographical area. Species of genera Cladosporium, Penicillium, and Alternaria, frequently cited as typical colonizers of historical glass (Drewello and Weissmann, 1997; SchabereiterGurtner et al., 2001; Rodrigues et al., 2014), were not found in this research. This fact could also be related to the different chronology and location of the stained-glass windows analysed in this work.

The low fungal diversity detected on the studied stained-glass windows is explained by the fact that culture methods were used before the molecular biology techniques were applied. Culture methods were used to obtain viable species and guarantee their survival during the laboratory-based biodeterioration experiment.

\subsection{Biodeterioration of the glass reproductions}

\subsubsection{Optical microscopy}

In general, the replicated samples showed a smooth surface at the beginning of the experiment (Fig. 2 a, b, c), despite of few surface features that were inherited during the manufacturing process, mainly in glasses $\mathrm{C} 2$ and $\mathrm{C} 3$. At the end of five months of incubation, the inoculated glass samples showed several morphological alterations (Fig. 2 d, e, f), such as fungal fingerprints together with crystal formation. These crystalline substances were detected 
by optical microscopy but their size was too small to be identified by $\mu$-Raman spectroscopy. Few iridescent areas were also observed on the surface. They could be attributed to an initial glass deterioration mechanism. In addition, a decrease of surface smoothness and transparency could be observed by the naked eye in all the samples after the inoculation.
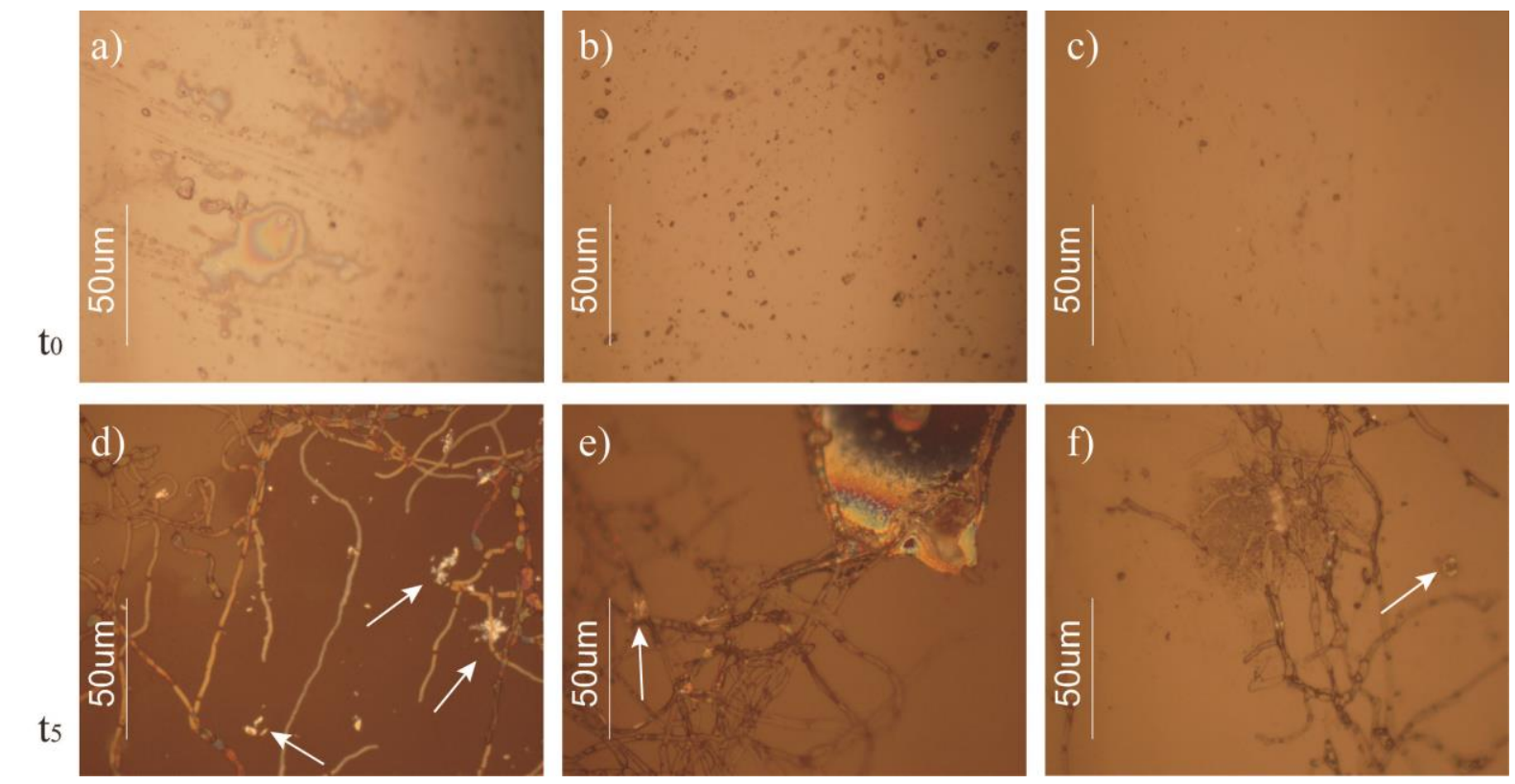

Figure 2: Comparison of surface morphology on replica samples before the inoculation $\left.\left(t_{0}\right): a\right)$ Sample from composition C1; b) Sample from composition C2; c) Sample from composition C3; and replica glasses after 5 months of incubation $\left(t_{5}\right)$ : d) Well developed hyphae surrounded by small crystals (arrows) in sample C1; e) Corrosion spot at the top of the image and small crystal (arrow) in sample C2;

f) Sample C3 showing few hyphae on the glass surface and a small isolated crystal (arrow).

The fungi under investigation showed high affinity with the three glass compositions, in accordance with previous biodeterioration studies (Gorbushina and Palinska, 1999; Rodrigues et al., 2014). Although these samples were inoculated only with spores without any nutrients, some dense mycelia were able to grow on the inoculated glass surfaces. The inoculum was deposited in the middle of the samples, but at the end of the incubation period, fungal hyphae were not limited to this area but to the complete surface area, particularly in glasses $\mathrm{C} 1$ and C2. It is known that fungal mycelia can induce mechanical destruction, resulting in tensile stress and cracks in the glass surface (Müller et al., 2001; Piñar et al., 2013). Furthermore, the biochemical processes induced by cell growth are the production of organic and inorganic acids, extracellular enzymes and metabolites, which lead to $\mathrm{pH}$ changes on glass surface (Callot et al., 1987; Drewello and Weissmann, 1997; Müller et al., 2001). The decrease of pH by fungi can initiate the interchange between cations from the glass and the excreted metabolites, which can cause the weakening of the glass matrix making easily the penetration of the fungi inside the glass. 


\subsubsection{SEM-EDS}

SEM-EDS analyses complemented the understanding on the physical and chemical alterations of the inoculated glass samples. Hyphae fingerprints were almost imperceptible in samples with the composition C1 (Fig. 3 a). However, in some regions it was possible to identify etched patterns after the cleaning procedure (Fig. $3 \mathrm{~b}$ ), which indicated that the process for fungi removal was effective. The sample from composition $\mathrm{C} 2$ showed imprints of fungal hyphae that covered the entire surface and also spores next to the area where the inoculum was deposited (Fig. 3 c).
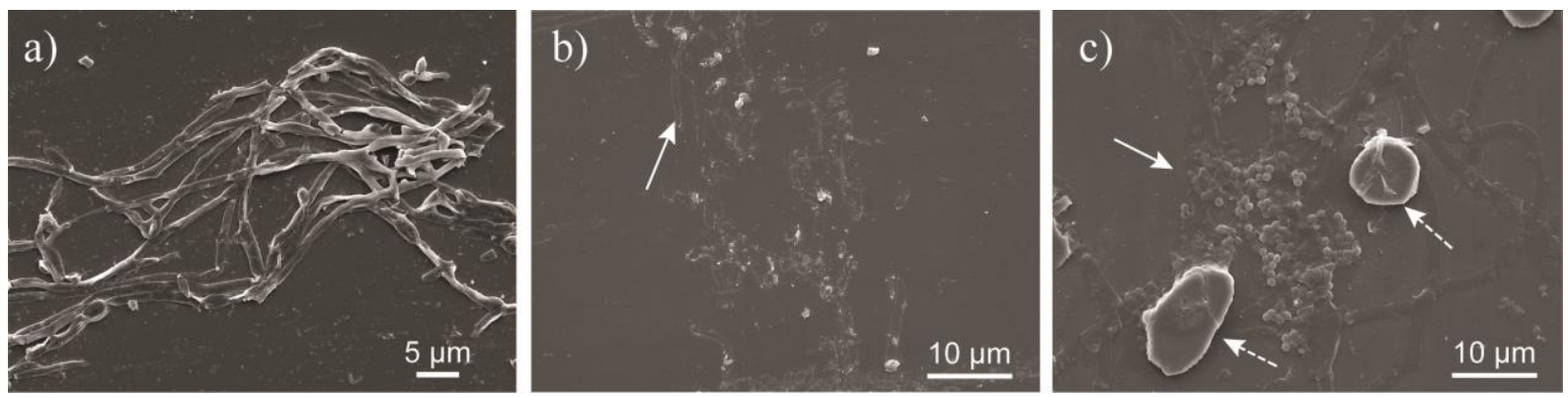

Figure 3: Figure 3: SEM images of: a) Hyphae residue on sample C1, b) Superficial etching on sample C1, c) Spores (white arrow) in the middle of fungi residue (dashed arrows) on sample C2; after cleaning procedure after 5 months of inoculation.

It was not observed cracking on the tested samples, which suggested that the fungi did not strongly adhere to the glass surface. However, a rough halo surrounding hyphae fingerprints was detected in the samples with the composition C3 (Fig. 4 a) and C2 (Fig. 4 b). This latter one showed the alteration spread in larger areas of the surface, which could be attributed to the metabolites produced by the fungal activity during the experiment. The low alteration observed on the surface of the tested samples is in agreement with previous studies (Garcia-Vallès; et al., 2003; Piñar et al., 2013), where it was showed that Na-rich glass compositions were hardly decayed. 

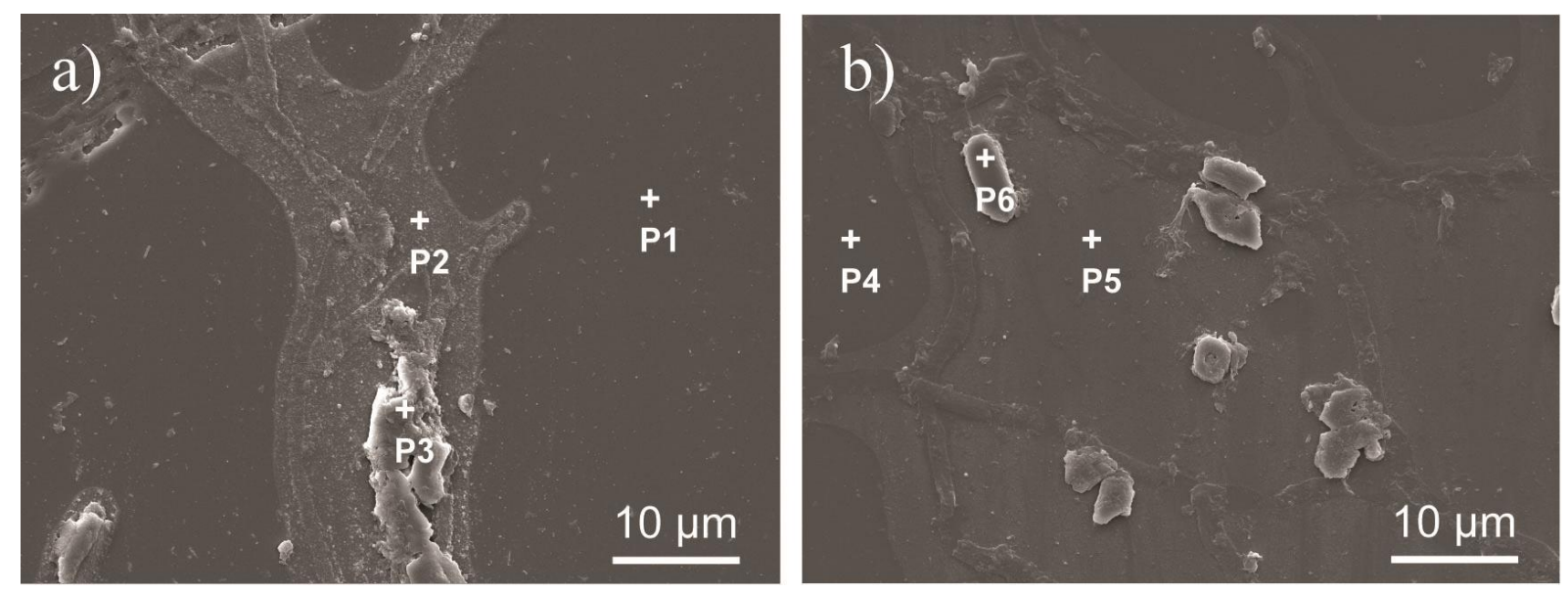

Figure 4: Figure 4: SEM images of the morphological alterations produced on inoculated samples: a) Rough halo caused by hyphae activity on the surface of sample C3; b) Hyphae fingerprints and residues on the surface of sample C2. P1-P6: EDS microanalysis (Table 3).

EDS analyses were performed in both compositions in order to identify the differences between the unaltered glass and the area previously covered by the hyphae (Table 3 ). The analyses of the area with fungal metabolites in sample $\mathrm{C} 3$ showed a slight depletion of $\mathrm{CaO}$ and a slight increase of $\mathrm{SiO}_{2}$. This suggested the formation of a silica-gel layer in these areas which could be related to an initial stage of the biocorrosion process (Gorbushina and Palinska, 1999; Vilarigues et al., 2011). The increase of the roughness in the surface previously covered by the fungi was related to the chemical alteration of glass. This phenomenon was observed only in areas close to the place where the inoculum was deposited. Despite showing the same alteration but more spread, EDS analysis of the sample C2 indicated an atypical increase of calcium, which is probably related to the residues of the organic material from the hyphae (Drewello et al., 2000). A slight depletion of $\mathrm{Al}_{2} \mathrm{O}_{3}$ was also observed, which could be related to the leaching of aluminum from the glass surface. Some authors (Krumbein et al., 1991; Kaiser et al., 1996) already discussed that cations from elements such as aluminium, calcium, iron, potassium, magnesium or sodium are released from material and assimilated by the biomass. 
Table 3: EDS microanalysis (wt. \%) of the morphological alterations highlighted in Figure 3. (P1: pristine glass, P2: altered glass, P3: fungal residue, P4: pristine glass, P5: altered glass, P6: fungal residue)

\begin{tabular}{|c|c|c|c|c|c|c|c|c|}
\hline Sample & Analysis & $\mathrm{MgO}$ & $\mathrm{Na}_{2} \mathrm{O}$ & $\begin{array}{l}\mathrm{Al}_{2} \mathrm{O} \\
3 \\
\end{array}$ & $\begin{array}{l}\mathrm{SiO} \\
2\end{array}$ & $\mathrm{~K}_{2} \mathrm{O}$ & $\mathrm{CaO}$ & $\mathrm{PbO}$ \\
\hline \multirow{3}{*}{$\mathrm{C} 3$} & P1 (pristine glass) & -- & 6.3 & 3.8 & 74.6 & 1.9 & 11.6 & 1.8 \\
\hline & P2 (altered glass) & -- & 6.7 & 3.1 & 76.9 & 2.3 & 9.9 & 1.2 \\
\hline & $\begin{array}{l}\text { P3 (fungal } \\
\text { residues) }\end{array}$ & 1.5 & 1.6 & -- & 30.8 & -- & 66.1 & -- \\
\hline \multirow{3}{*}{$\mathrm{C} 2$} & P4 (pristine glass) & -- & 11.1 & 6.3 & 71.6 & 2.6 & 8.4 & -- \\
\hline & P5 (altered glass) & -- & 11.2 & 5.4 & 72.6 & -- & 10.7 & -- \\
\hline & $\begin{array}{l}\text { P6 (fungal } \\
\text { residues) }\end{array}$ & 2.3 & 1.8 & -- & 6.3 & -- & 89.6 & -- \\
\hline
\end{tabular}

Regarding the different evolution of fungal biodeterioration, it was related to the chemical composition of the replica glass. The three replica glasses differed mainly in the amount of $\mathrm{Na}_{2} \mathrm{O}, \mathrm{Al}_{2} \mathrm{O}_{3}$, and $\mathrm{PbO}$. Composition $\mathrm{C} 1$ (MEP) and $\mathrm{C} 2$ (BPM) showed similar contents of $\mathrm{Na}_{2} \mathrm{O}$ and $\mathrm{CaO}$, but $\mathrm{C} 2$ showed low concentration of $\mathrm{P}_{2} \mathrm{O}_{5}$. The amount of $\mathrm{PbO}$ in composition $\mathrm{C} 3(\mathrm{BSN})$ is higher than in the other replica samples.

The replica glass $\mathrm{C} 2$ was the most damaged glass by fungal colonization. Contrary to $\mathrm{C} 1$ and $\mathrm{C} 3, \mathrm{C} 2$ glasses had $\mathrm{P}_{2} \mathrm{O}_{5}\left(0.2\right.$ wt. \%) and a higher concentration of $\mathrm{Al}_{2} \mathrm{O}_{3}$ (6.7 wt. \%), as displayed in Table 1. Phosphorus and aluminium are among a large number of elements that microbiota preferentially attack (Krumbein et al., 1991). Although it has been already discussed in the literature (Drewello and Weissmann, 1997), the incorporation of $\mathrm{P}_{2} \mathrm{O}_{5}$ and $\mathrm{Al}_{2} \mathrm{O}_{3}$ as glass network-forming in association with $\mathrm{Ag}_{2} \mathrm{O}$ results in a glass with microbiocide properties. However, without the silver, the biodeterioration still occurs. Our results are in agreement with that, since $\mathrm{P}_{2} \mathrm{O}_{5}$ and $\mathrm{Al}_{2} \mathrm{O}_{3}$ were incorporated as glass network-stabilizers. On the other hand, $\mathrm{PbO}$ inhibits the microbial growth (Drewello and Weissmann, 1997; Müller et al., 2001), and the $\mathrm{PbO}$ content on the composition $\mathrm{C} 2$ is almost nil $(0.08 \mathrm{wt} . \%)$ in comparison to the $\mathrm{C} 1$ and C3 composition (Table 1). This explains the extension of damages produced by microbial attack in the glass surface. The chemical durability of silicate substrate is correlated to the presence of biologically essential elements and trace metals, higher concentrations of transition metals in glass results in a decrease of its durability (Drewello and Weissmann, 1997). In the replica samples, the amounts of transition metals are low and the growth-stimulating effect could not be enhanced.

Control glass samples showed dark stains on the surface caused by the high relative humidity and temperature. Unlike the inoculated set, control samples did not present any crystal formation, leading to presume that this alteration was related to the fungal activity. 


\subsubsection{FTIR-ATR}

FTIR spectra were similar before and after the laboratory-based biodeterioration experiment, which confirmed that the glasses were stable and suffered minor alterations after the test (Fig. 5). The sample from composition $\mathrm{C} 1$ showed a slight increase in the asymmetric stretching bands of $\mathrm{SiO}_{2}$, in transverse optical (TO) and longitudinal optical components (LO), and also the increase of $\mathrm{SiO}^{-}$symmetric stretching bands that could be related to an initial formation of hydration layer. This alteration was manifested in form of etched surface (Fig. 3 b) and iridescence, as it was seen by the naked eye in the sample.

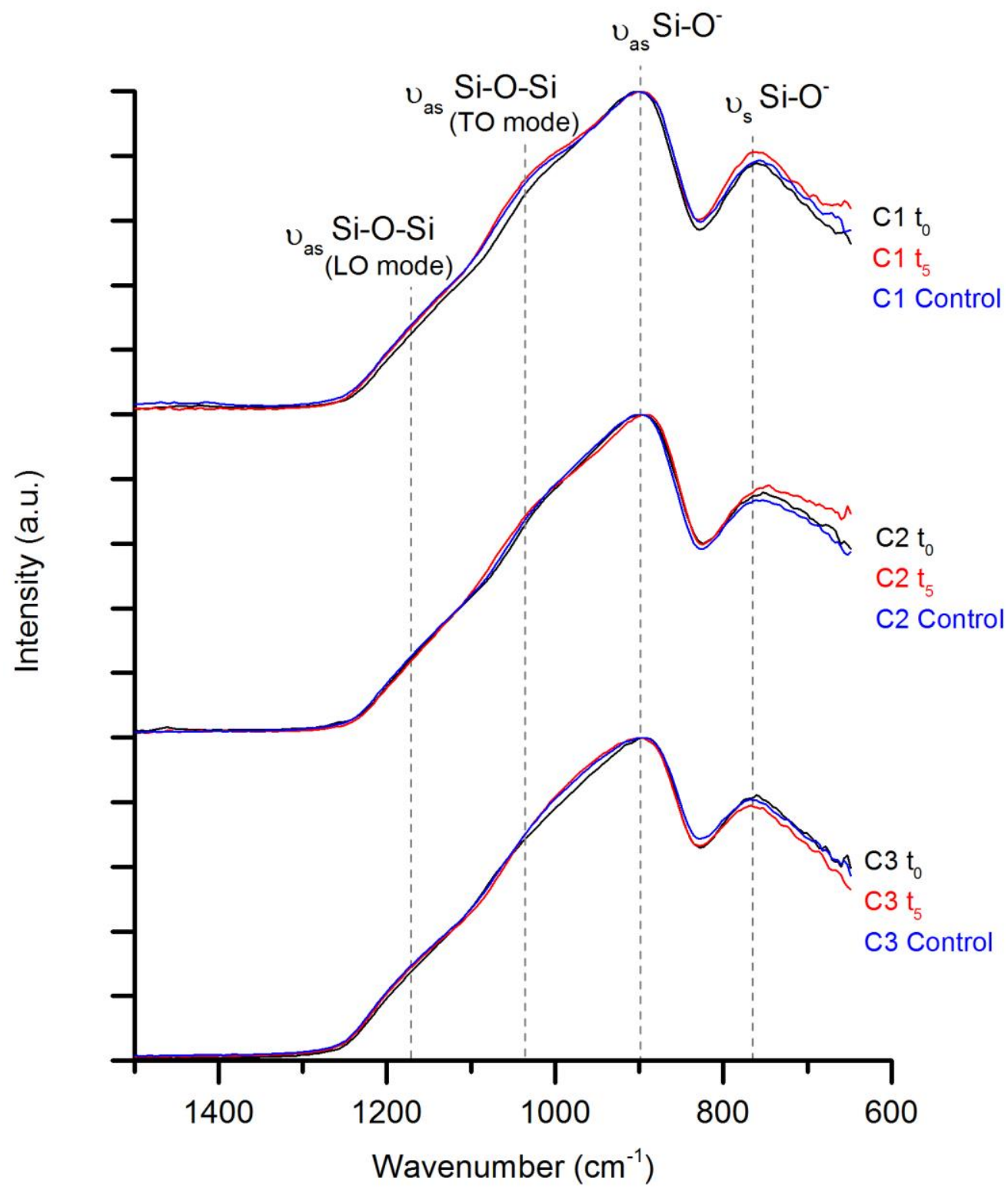

Figure 5: Figure 5: Normalized FTIR spectra of the original replica samples $\left(\mathrm{C1}_{\mathrm{t}}, \mathrm{C} \mathbf{2}_{\mathrm{t}}\right.$ and $\left.\mathrm{C3}_{\mathrm{t}}\right)$, the inoculated replica samples after 5 months of incubation $\left(\mathrm{Cl}_{\mathrm{t}}, \mathrm{C}_{2} \mathrm{t}_{5}\right.$ and $\left.\mathrm{C}_{\mathrm{t5}}\right)$ and the non-inoculated replica samples after 5 months of incubation ( $\mathrm{C} 1_{\text {control, }}, \mathrm{C} 2$ control and $\mathrm{C} 3$ control). Type of vibration: v: stretching 
As it has been previously demonstrated (Rodrigues et al., 2014; Palomar et al., 2017), relative humidity plays an important role in glass deterioration. Environmental fluctuations lead to the formation of cracks due to hydration and dehydration cycles (Hogg et al., 1998). Nevertheless, soda-lime silicate glass is commonly known by its stability in comparison with other historical glass compositions, such as potash-lime silicate, because their hydration process is long and slow (García-Heras et al., 2005; Piñar et al., 2013; Palomar et al., 2017). The chemical stability of the glass in a humid environment favoured the poor interaction between the inoculated fungi and the glass matrix since the higher supply of adsorbed water is required to make the glass more attractive for microbes (Drewello et al., 2000).

\section{Recommendations}

As result of this study, some recommendations for the conservation of stained-glass windows in a tropical environment are proposed:

- Periodical cleaning shall be adopted in order to avoid fungal growth in the inner surface of the panels;

- Preventive strategies such as the installation of protective glazing system, very widespread in Europe, shall be avoided, since it could change the thermohygrometric cycles and accelerate the microbial growth.

- Development of new sustainable cleaning methods for efficient fungal removal from the glass surface.

\section{Conclusions}

After five months of fungal inoculation the replica samples from modern stained-glass windows, dense mycelia were observed on the glass surfaces. The main physical and chemical alterations observed on the glass surfaces were iridescent stains, crystal formation, slight decrease of the surface smoothness, and hyphae fingerprints. Although fungi have clearly damaged the three different types of glass samples, soda-lime silicate compositions showed good resistance to fungal attack. 


\section{Acknowledgements}

The authors are grateful to Santa Izabel Cemetery, Basílica Santuário de Nazaré, Sistema Integrado de Museus e Memoriais (SIMM), Departamento de Patrimônio Histórico Artístico e Cultural (DPHAC/SECULT) for the collaboration. AMCP is indebted to Dr. R. Wiley (VICARTE, Portugal) for producing the glass roundels employed in this experiment, to Dr. S. Sequeira and I. Borges for the assistance during the inoculum preparation, and to A. Rodrigues for helping with SEM/EDS analyses. This work was supported by the Coordination for the Improvement of Higher Education Personnel (CAPES) through a doctoral scholarship to AMCP (BEX 0418/14-5), by the Ministério de Ciência e Tecnologia de Portugal through a postdoctoral scholarship to TP (SFRH/BPD/108403/2015) and FCT projects UID/EAT/00729/2013 and UID/Multi/04349/2013. 


\section{References}

Ahrazem, O., Gómez-Miranda, B., Prieto, A., Bernabé, M., Leal, J.A., 2000. Heterogeneity of the genus Myrothecium as revealed by cell wall polysaccharides. Arch. Microbiol. 173, 296-302. https://doi.org/10.1007/s002030000149

Amend, A.S., Seifert, K.A., Samson, R., Bruns, T.D., 2010. Indoor fungal composition is geographically patterned and more diverse in temperate zones than in the tropics. Proc. Natl. Acad. Sci. 107, 13748-13753. https://doi.org/10.1073/pnas.1000454107

Banerjee, D., Strobel, G.A., Booth, E., Geary, B., Sears, J., Spakowicz, D., Busse, S., 2010. An endophytic Myrothecium inundatum producing volatile organic compounds. Mycosphere 1, 229-240.

Bastos, T.X., Pacheco, N.P., Nechet, D., Sá, T.D. de A., 2002. Aspectos climáticos de Belém nos últimos cem anos, 1st ed, Série Documentos (Embrapa Amazônia Oriental). Embrapa Amazônia Oriental, Belém.

Cabral, C., 1995. Clima e morfologia urbana em Belém. NUMA/UFPA, Belém.

Callot, G., Maurette, M., Pottier, L., Dubois, A., 1987. Biogenic etching of microfractures in amorphous and crystalline silicates. Lett. to Nat. 328, 147-149.

Campbell, J.L., Boyd, N.I., Grassi, N., Bonnick, P., Maxwell, J.A., 2010. The Guelph PIXE software package IV. Nucl. Instruments Methods Phys. Res. Sect. B Beam Interact. with Mater. Atoms 268, 3356-3363. https://doi.org/https://doi.org/10.1016/j.nimb.2010.07.012

Carmona, N., Laiz, L., Gonzalez, J.M., García-Heras, M., Villegas, M.A., Saiz-Jimenez, C., 2006. Biodeterioration of historic stained glasses from the Cartuja de Miraflores (Spain). Int. Biodeterior. Biodegrad. 58, 155-161. https://doi.org/10.1016/j.ibiod.2006.06.014

Carvalho, R.M. de, 2013. Ecosystem Services and Urban Vegetation Coverage in Belém: The influence on noise pollution, air pollution and climate regulation. Diss. Universidade Federal do Pará. https://doi.org/https://doi.org/10.1017/CBO9781107415324.004

Castro, A.R. da C., 2009. Aplicação de Sensoriamento Remoto na ánalise espaço-temporal das Ilhas de Calor e Frescor Urbanas no município de Belém- Pará, nos anos de 1997 e 2008. Universidade Federal do Pará.

Corrêa Pinto, A., Macedo, M.F., Vilarigues, M., 2018a. The conservation of stained-glass windows in Latin America: A literature overview. J. Cult. Herit. 1-10. https://doi.org/https://doi.org/10.1016/j.culher.2018.04.019

Corrêa Pinto, A., Vilarigues, M., Sanjad, T., 2015. The window glass and stained glass windows of Belém: a cultural history of the Brazilian Amazon region, in: Baumgartner, E., Fünfschilling, S., Gartenmeister, M., Pury-Gysel, A. de, Trümpler, S., Wolf, S. (Eds.), AIHV Annales Du 20e Congrès 2015. Vitrocentre, Romont, pp. 699-702.

Corrêa Pinto, A.M., Sanjad, T.A.B.C., Angélica, R.S., Costa, M.L. da, Paiva, R.S., Palomar, T., 2018b. 19th century stained glass windows from Belém do Pará (Brazil): analytical characterization and pathology. Boletín la Soc. Española Cerámica y Vidr. 133-141. https://doi.org/https://doi.org/10.1016/j.bsecv.2017.10.005

De Carvalho, R.M., Szlafsztein, C.F., 2018. Urban vegetation loss and ecosystem services: The influence on climate regulation and noise and air pollution. Environ. Pollut. 245, 844-852. https://doi.org/10.1016/J.ENVPOL.2018.10.114

Djian, C., Pijarowski, L., Ponchet, M., Arpin, N., Favre-Bonvin, J., 1991. Acetic acid: A selective nematicidal metabolite from culture filtrates of paecilomyces lilacinus (Thom) samson and trichoderma longibrachiatum rifai. Nematologica 37, 101-112. https://doi.org/10.1163/187529291X00105

Drewello, R., Weissmann, R., 1997. Microbially influenced corrosion of glass. Appl. Microbiol. Biotechnol. 47, 337-346. https://doi.org/10.1007/s002530050937 
Drewello, U., Weißmann, R., Rölleke, S., Müller, E., Wuertz, S., Fekrsanati, F., Troll, C., Drewello, R., 2000. Biogenic surface layers on historical window glass and the effect of excimer laser cleaning. J. Cult. Herit. 1, S161-S171. https://doi.org/https://doi.org/10.1016/S1296-2074(00)00183-7

Fravel, D., Olivain, C., Alabouvette, C., 2003. Fusarium oxysporum and its biocontrol. New Phytol. 157, 493-502. https://doi.org/10.1046/j.1469-8137.2003.00700.x

García-Heras, M., Carmona, N., Gil, C., Villegas, M.A., 2005. Neorenaissance/Neobaroque stained glass windows from Madrid: A characterisation study on some panels signed by the Maumejean Fréres company. J. Cult. Herit. 6, 91-98. https://doi.org/https://doi.org/10.1016/j.culher.2004.12.001

Garcia-Vallès;, Gimeno-Torrente;, Martínez-Manent;, Fernández-Turiel, 2003. Medieval stained glass in a Mediterranean climate: Typology, weathering and glass decay, and associated biomineralization processes and products 88, 1996-2006.

Gorbushina, A.A., Palinska, K.A., 1999. Biodeteriorative processes on glass: Experimental proof of the role of fungi and cyanobacteria. Aerobiologia (Bologna). 15, 183-191. https://doi.org/https://doi.org/10.1023/A:1007616614172

Gordon, T.R., Martyn, R.D., 1997. The Evolutionary Biology Of Fusarium Oxysporum. Annu. Rev. Phytopathol. 35, 111-128.

Gostinčar, C., Lenassi, M., Gunde-Cimerman, N., Plemenitaš, A., 2011. Fungal Adaptation to Extremely High Salt Concentrations. Adv. Appl. Microbiol. 77, 71-96. https://doi.org/10.1016/B978-0-12-387044-5.00003-0

Gunde-Cimerman, N., Zalar, P., de Hoog, G.S., Plemenitaš, A., 2000. Hypersaline water in salterns-natural ecological niches for halophilic black yeasts. FEMS Microbiol Ecol 32, 235-240.

Hogg, S., McPhail, D.S., Oakley, V., Rogers, P., 1998. Cracking crizzling - eight years of collaborative research. Conserv. J. 9, 10-12.

Jones, F.L., 1945. Deterioration of glass in tropical use. J. Am. Ceram. Soc. 28, 32.

Kaiser, J.P., Trumpler, S., Raschle, P., 1994. Growth of Taeniolina-Deightoni on Medieval Stained-Glass. Werkstoffe und Korrosion - Mater. Corros. 45, 125-127.

Kaiser, J.P., Trümpler, S., Raschle, P., 1996. Fungal growth on medieval glass paintings, in: Heitz, E., Flemming, H.C., Sand, W. (Eds.), Microbially Influenced Corrosion of Materials. Springer-Verlag Berlin Heidelberg, Berlin, pp. 353-357.

Kerner-Gang, W., 1968. Zur Frage der Entstehung von Schimmelpilzspuren auf optischen Gläsern(Contribution to the development of mould etching patterns on optical lenses). Mater. und Org.

Kogej, T., Stein, M., Volkmann, M., Gorbushina, A.A., Galinski, E.A., Gunde-Cimerman, N., 2007. Osmotic adaptation of the halophilic fungus Hortaea werneckii: Role of osmolytes and melanization. Microbiology 153, 4261-4273. https://doi.org/10.1099/mic.0.2007/010751-0

Krumbein, W.E., Gorbushina, A., Rudolph, C., Urzì, C.E., 1993. Biological investigations on the question of organic and inorganic eutrophication induced biocorrosions and biogenic deposits on late mediaeval church windows of the cathedral of Tours and St. Catherine in Oppenheim, in: Welck, F. v., Filtz, J.-F. (Eds.), Conservation Commun d'un Patrimoine Commun. Champs-sur-Marne, pp. 269-275.

Krumbein, W.E., Urzì, C.E., Gehrmann, C., 1991. Biocorrosion and biodeterioration of antique and medieval glass. Geomicrobiol. J. 9, 139-160. https://doi.org/10.1080/01490459109385995

Lombardo, T., Ionescu, A., Lefèvre, R.A., Chabas, A., Ausset, P., Cachier, H., 2005. Soiling of silica-soda-lime float glass in urban environment: Measurements and modelling. Atmos. Environ. 39, 989-997. https://doi.org/https://doi.org/10.1016/j.atmosenv.2004.10.030 
Marvasi, M., Vedovato, E., Balsamo, C., Macherelli, A., Dei, L., Mastromei, G., Perito, B., 2009. Bacterial community analysis on the Mediaeval stained glass window "Natività" in the Florence Cathedral. J. Cult. Herit. 10, 124-133. https://doi.org/10.1016/j.culher.2008.08.010

McMullin, D.R., Renaud, J.B., Barasubiye, T., Sumarah, M.W., Miller, J.D., 2017. Metabolites of Trichoderma species isolated from damp building materials. Can. J. Microbiol. 63, 621632. https://doi.org/10.1139/cjm-2017-0083

Michielse, C.B., Rep, M., 2009. Pathogen profile update: Fusarium oxysporum. Mol. Plant Pathol. 10, 311-324. https://doi.org/10.1111/j.1364-3703.2009.00538.x

Müller, E., Drewello, U., Drewello, R., Weißmann, R., Wuertz, S., 2001. In situ analysis of biofilms on historic window glass using confocal laser scanning microscopy 2, 31-42.

Najafzadeh, M.J., Sun, J., Vicente, V., Xi, L., Gerrits Van Den Ende, A.H.G., De Hoog, G.S., 2010. Fonsecaea nubica sp. nov, a new agent of human chromoblastomycosis revealed using molecular data. Med. Mycolgy 48, 800-806. https://doi.org/10.3109/13693780903503081

Palomar, T., Chabas, A., Bastidas, D.M., de la Fuente, D., Verney-Carron, A., 2017. Effect of marine aerosols on the alteration of silicate glasses. J. Non. Cryst. Solids 471, 328-337. https://doi.org/https://doi.org/10.1016/j.jnoncrysol.2017.06.013

Palomar, T., de la Fuente, D., Morcillo, M., Alvarez de Buergo, M., Vilarigues, M., 2019. Early stages of glass alteration in the coastal atmosphere. Build. Environ. 147, 305-313. https://doi.org/https://doi.org/10.1016/j.buildenv.2018.10.034

Palomar, T., Redol, P., Cruz Almeida, I., Pereira da Silva, E., Vilarigues, M., 2018. The Influence of Environment in the Alteration of the Stained-Glass Windows in Portuguese Monuments. Heritage 1, 365-376. https://doi.org/10.3390/heritage1020025

Pantoja, P.A.V., 2016. A termografia infravermelha na salvaguarda de monumentos culturais como método destrutivo de diagnóstico. Universidade Federal do Pará.

Peel, M.C., Finlayson, B.L., Mcmahon, T.A., 2007. Updated world map of the Koppen-Geiger climate classification. Hydrol. Earth Syst. Sci. 11, 1633-1644. https://doi.org/http://doi.org/10.5194/hess-11-1633-2007

Pereira, B.F.P., Melo, L.E. de, Costa, P.F. da, 2013. Fungos anemófilos isolados na cidade de Belém, Estado do Pará - Brasil. Rev. Eletrônica Biol. 6, 82-93. https://doi.org/https://doi.org/10.1016/j.lwt.2014.05.063

Perez y Jorba, M., Dallas, J.P., Bauer, C., Bahezre, C., Martin, J.C., 1980. Deterioration of stained glass by atmospheric corrosion and micro-organisms. J. Mater. Sci. 15, 16401647. https://doi.org/10.1007/BF00550580

Piñar, G., Garcia-Vallès, M., Gimeno-Torrente, D., Fernandez-turiel, J.L., Ettenauer, J., Ster, K., 2013. Microscopic, chemical, and molecular-biological investigation of the decayed medieval stained window glasses of two Catalonian churches. Int. Biodeterior. Biodegradation 84, 388-400. https://doi.org/https://doi.org/10.1016/j.ibiod.2012.02.008

Rodionova, M.S., Razumovskaya, Z.G., 1972. Mold growth on optical glass surfaces, in: Flerov, B. (Ed.), Problemy Biologicheskikh Povrezhdenii i Obrastaniia Materialov Izdelii, Sooruzhenii. Nauka, Moscow, pp. 79-91.

Rodrigues, A., Fearn, S., Palomar, T., Vilarigues, M., 2018. Early stages of surface alteration of soda-rich-silicate glasses in the museum environment. Corros. Sci. 143, 362-375. https://doi.org/10.1016/j.corsci.2018.08.012

Rodrigues, A., Gutierrez-Patricio, S., Miller, A.Z., Saiz-Jimenez, C., Wiley, R., Nunes, D., Vilarigues, M., Macedo, M.F., 2014. Fungal biodeterioration of stained-glass windows. $\begin{array}{llll}\text { Int. } & \text { Biodeterior. } & \text { Biodegrad. }\end{array}$ https://doi.org/https://doi.org/10.1016/j.ibiod.2014.03.007

Schabereiter-Gurtner, C., Piñar, G., Lubitz, W., Rölleke, S., 2001. Analysis of fungal 
communities on historical church window glass by denaturing gradient gel electrophoresis and phylogenetic 18S rDNA sequence analysis. J. Microbiol. Methods 47, 345-354. https://doi.org/10.1016/S0167-7012(01)00344-X

Sequeira, S.O., Laia, C.A.T., Phillips, A.J.L., Cabrita, E.J., Macedo, M.F., 2017. Clotrimazole and calcium hydroxide nanoparticles: A low toxicity antifungal alternative for paper conservation. J. Cult. Herit. 120, 203-5+215. https://doi.org/10.1016/j.culher.2016.12.004

Shirakawa, M.A., John, V.M., Mocelin, A., Zilles, R., Toma, S.H., Araki, K., Toma, H.E., Thomaz, A.C., Gaylarde, C.C., 2016. Effect of silver nanoparticle and TiO2 coatings on biofilm formation on four types of modern glass. Int. Biodeterior. Biodegrad. 108, 175180. https://doi.org/https://doi.org/10.1016/j.ibiod.2015.12.025

Shirakawa, M.A., Zilles, R., Mocelin, A., Gaylarde, C.C., Gorbushina, A., Heidrich, G., Giudice, M.C., Del Negro, G.M.B., John, V.M., 2015. Microbial colonization affects the efficiency of photovoltaic panels in a tropical environment. J. Environ. Manage. 157, 160 167. https://doi.org/https://doi.org/10.1016/j.jenvman.2015.03.050

Silva, L.S. e, Travassos, L., 2008. Problemas ambientais urbanos: desafios para a elaboração de políticas públicas integradas. Cad. Metrópole 19, 27-47.

Vilarigues, M., Redol, P., Machado, A., Rodrigues, P.A., Alves, L.C., Da Silva, R.C., 2011. Corrosion of 15th and early 16th century stained glass from the monastery of Batalha studied with external ion beam. Mater. Charact. 62, 211-217. https://doi.org/https://doi.org/10.1016/j.matchar.2010.12.001

Visagie, C.M., Hirooka, Y., Tanney, J.B., Whitfield, E., Mwange, K., Meijer, M., Amend, A.S., Seifert, K.A., Samson, R.A., 2014. Aspergillus, Penicillium and Talaromyces isolated from house dust samples collected around the world. Stud. Mycol. 78, 63-139. https://doi.org/10.1016/j.simyco.2014.07.002

White, T.J., Bruns, T., Lee, S., Taylor, J., 1990. Amplification and direct sequencing of fungi ribosomal RNA genes for phylogenetics., in: Innis, M.A., Gelfand, D.H., Sninsky, J.J., White, T.J. (Eds.), PCR Protocols. A Guide to Methods and Applications. Academic Press, San Diego, pp. 315-322. 


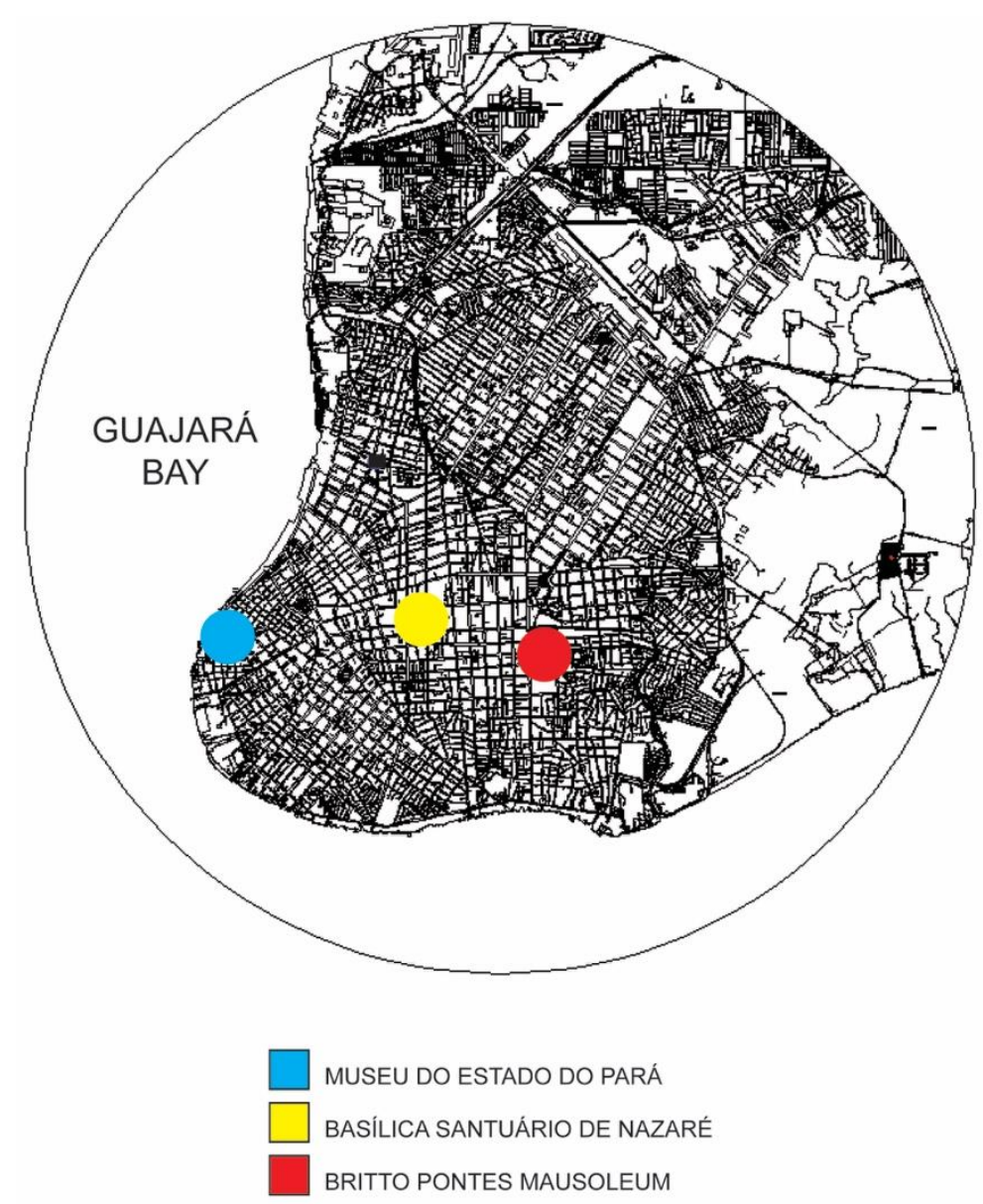

Supplementary Fig S1. The buildings with Modern stained-glass windows where the historical glass samples were characterized and their location within the city's districts. 